\title{
UPAYA PENINGKATAN KESADARAN MASYARAKAT DALAM PENCEGAHAN PENYAKIT DIABETES MELITUS DI DESA PISANGAN JAYA, KABUPATEN TANGERANG
}

\author{
Mellysa Rahmita $^{1)}$, Citra Trisna ${ }^{2)}$, Wenti Dwi Febriani ${ }^{3)}$ \\ 1,2,3) Jurusan Analis Kesehatan Poltekkes Kemenkes Banten \\ Email: mellysarahmita@gmail.com
}

\begin{abstract}
ABSTRAK
Diabetes Melitus merupakan penyakit yang termasuk dalam kelompok Penyakit Tidak Menular, penyakit ini ditandai dengan meningkatnya kadar gula darah akibat gangguan fungsi insulin. Hasil Riset Kesehatan Dasar pada tahun 2013, menunjukan angka kejadian Diabetes Melitus di Indonesia mencapai 10 juta jiwa, sedangkan kejadian secara global diabetes melitus adalah 415 Juta jiwa pada tahun 2015. Penyakit ini dapat dicegah dengan melakukan diet yang seimbang dan pola hidup yang baik. Faktor resiko yang menjadi perhatian penyakit ini ialah usia, jenis kelamin, lingkar perut, kurangnya aktifitas fisik, obesitas, hipertensi, dan pola makanan yang tidak baik. Dalam upaya pencegahan terjadinya peningkatan jumlah penyakit ini maka dibutuhkan pengetahuan dan kesadaran oleh masyarakat. Kegiatan pengabdian masyarakat dapat menjadi sarana untuk peningkatkan kesadaran masyarakat dengan memberikan pengetahuan tentang faktor resiko terjadinya penyakit Diabetes Melitus. Pengabdian masyarakat dilakukan dengan penyuluhan serta melakukan pemeriksaan kadar glukosa darah dan lingkar perut sehingga masyarakat dapat menerapkan pengetahuan yang sudah didapat untuk lebih meningkatkan kesadaran dalam menjaga kesehatan.
\end{abstract}

Kata Kunci : Diabetes Melitus, Lingkar perut, Gula darah

\begin{abstract}
Diabetes mellitus is a non-communicable disease, characterized by high levels of blood sugar due to impaired insulin function. The results of the Basic Health Research in 2013 showed that the occurence of diabetes mellitus in Indonesia reached 10 million cases, while it was 415 million cases in 2015 globally. This disease can be prevented by taking a balanced diet and a good lifestyle. Risk factors of this disease are age, gender, waist circumference, lack of physical activity, obesity, hypertension, and a poor diet. Knowledge and awareness are needed as an effort to prevent this disease. Community service activities can be a tool to increase public awareness by providing knowledge about risk factors for Diabetes Mellitus. Community service is carried out by informing and checking blood levels and waist circumference so that the community can apply the knowledge already obtained to further increase their awareness.
\end{abstract}

Key word : Diabetes mellitus, waist circumference, Blood sugar 


\section{PENDAHULUAN}

Diabetes Melitus (DM) merupakan penyakit yang berhubungan dengan sindrom metobolik yang memiliki ciri meningkatnya kadar glukosa darah atau dikenal dengan istilah hiperglikemi. Kondisi hiperglikemi ini dapat terjadi akibat gangguan sekresi, kerja insulin, atau oleh keduanya. Penyakit kronis seperti DM sangat rentan terhadap gangguan fungsi yang bisa menyebabkan kegagalan pada organ mata, ginjal, saraf, jantung dan pembuluh darah (WHO, 2016).

Menurut International Diabetes Federation (IDF) diabates merupakan masalah kesehatan terbesar secara global dan setiap tahunnya orang yang mengalami diabetes militus akan mengalami komplikasi. Diperkirakan pada tahun 2015 terdapat 415 juta orang dewasa yang mengalami diabetes diseluruh dunia dengan prevalensi 1 dari 11 orang mengalami diabetes dan akan terus meningkat. Pada tahun 2040 diperikirakan prevalensi naik 1 dari 10 orang didunia mengalami diabetes (IDF, 2015).

Di Indonesia sendiri berdasarkan dari Riset Kesehatan Dasar (Riskesdas) pada tahun 2013 penderita yang mengalami diabetes melitus berjumlah 9,116 juta. Indonesia menduduki peringkat ke-7 sebesar 10 juta tahun 2015, diperkirakan jumlahnya akan terus meningkat di tahun 2040 menjadi peringkat ke-6 sebesar 16,2 juta di seluruh dunia dari 10 negara penderita diabetes melitus (Rikesda 2013).

Orang dengan sindroma metabolik yang memiliki resiko diabetes mempunyai kondisi gula darah puasa yang meningkat, obesitas abdominal, kadar kolesterol yang tinggi, serta hipertensi. Lingkar pinggang berkorelasi kuat dengan obesitas dan risiko kardiovaskular. Lingkar pinggang terbukti lebih efektif dalam mendiagnosis sindroma metabolik dibandingkan dengan indeks massa tubuh (IMT) dan ukuran antropometri lainnya. Hal ini membuktikan pengukuran lingkar pinggang merupakan cara yang mudah, murah, dan efektif dalam mendeteksi sindroma metabolik (Jalal, 2006).

Peningkatan Lingkar perut sering terjadi pada ibu-ibu karena proses kehamilan dan melahirkan serta seiring peningkatan umur akan terjadi penurunan metabolisme dan diperburuk dengan kurangnya aktifitas fisik dan olahraga. Di desa Pisangan Jaya yang terletak di Kecamatan Sepatan terdapat kelompok pengajian yang aktif pelaksanaan pengajian setiap minggunya. Di desa Pisangan Jaya hanya terdapat satu puskesmas dan cukup jauh sehingga akan masyarakat akan sedikit terpapar informasi kesehatan. Oleh karena itu pada pengabdian masyarakat ini akan dilakukan di desa pisangan jaya, Kecamatan Sepatan.

\section{TINJAUAN PUSTAKA}

Diabetes mellitus (DM) didefinisikan sebagai suatu penyakit atau gangguan metabolisme kronis dengan multi etiologi yang ditandai dengan tingginya kadar gula darah disertai dengan gangguan metabolisme karbohidrat, lipid dan protein sebagai akibat insufisiensi fungsi insulin. Insufisiensi fungsi insulin dapat disebabkan oleh gangguan atau defisiensi produksi insulin oleh sel-sel beta Langerhans kelenjar pankreas, atau disebabkan oleh kurang responsifnya sel-sel tubuh terhadap insulin (WHO, 2016). Menurut International Diabetes Federation (IDF) tahun 2015, dalam metabolisme tubuh hormon insulin bertanggung jawab dalam mengatur kadar glukosa darah. Hormon ini diproduksi dalam pankreas kemudian dikeluarkan untuk digunakan sebagai sumber energi. Apabila di dalam tubuh kekurangan hormon insulin maka dapat menyebabkan hiperglikemi.

World Health Organization (WHO) sebelumnya telah merumuskan bahwa diabetes melitus merupakan sesuatu yang tidak dapat dituangkan dalam satu jawaban yang jelas dan singkat tetapi secara umum dapat dikatakan sabagai suatu penyakit kronis yang 
disebabkan oleh gangguan pankreas dalam memproduksi insulin atau kondisi dimana badan tidak dapat menggunakan insulin yang dihasilkan pankreas secara effisien. Kedua-dua keadaan ini akan menyebabkan peningkatan konsentrasi glukosa dalam darah (hiperglikemi) (WHO,2016).

Walaupun Diabetes mellitus merupakan penyakit kronik yang tida kmenyebabkan kematian secara langsung, tetapi dapat berakibat fatal bila pengelolaannya tidak tepat. Pengelolaan DM memerlukan penanganan secara multidisiplin yang mencakup terapi non-obat dan terapi obat. Semakin lama menderita DM maka kemungkinan terjadinya hiperglikemia kronik semakin besar. Hiperglikemia kronik dapat menyebabkan komplikasi diabetes melitus yaitu retinopati, nefropati, PJK dan ulkus diabetikum.

\section{Tipe diabetes}

a. Diabetes Melitus Tipe I

Dikenal sebagai Insulin Dependent Diabetes Melitus (IDDM). Diabetes Melitus tipe ini jarang terjadi, diperkirakan sekitar 5-10\% dari keseluruhan populasi penderita DM. Pada Diabetes Melitus tipe I terdapat ketidakmampuan untuk menghasilkan insulin oleh sel beta pankreas yang rusak karena autoimun, sehingga pada tipe ini pasien sangat tergantung terhadap pemberian insulin.

\section{b. Diabetes Melitus Tipe II}

Dikenal sebagai non Insulin Dependent Diabetes Melitus (NIDDM). Faktor genetik maupun lingkungan mempunyai peranan yang penting dalam menyebabkan terjadinya DM tipe II. Pada DM tipe II terdapat dua masalah yang berhubungan dengan insulin, yaitu resintesi insulin dan gangguan sekresi insulin. Pada kondisi resintesi insulin terjadi gangguan ikatan antara insulin dan reseptornya pada dinding sel sehingga insulin menjadi tidak efektif untuk menstimulasi pengambilan glukosa oleh jaringan. Untuk mengatasi resistensi insulin dan peningkatan glukosa oleh dalam darah, sel-sel beta pankreas akan meningkatkan produksi insulin sehingga kadar glukosa darah akan dipertahankan dalam keadaan normal.

\section{c. Diabetes Melitus Tipe III}

Dikenal sebagai Diabetes Melitus Gestasional yang terjadi pada masa kehamilan dan dapat pulih setelah melahirkan. Kondisi diabetes pada kehamilan ini dapat membahayakan janin dan sang ibu. Resiko yang dapat terjadi adalah makrosomia dimana berat badan janin lebih dari normal. Bayi yang lahir dari ibu yang mengalami gestasional diabetes memiliki resiko mengalami diabetes melitus tipe 2 . Ibu yang mengalami hiperglikemi selama kehamilan dapat mengkontrol kadar glukosa darah dengan diet sehat, olahraga ringan, dan selalu mengontrol kadar glukosa darah (IDF, 2015).

\section{Lingkar Perut}

kriteria sindroma metabolik meliputi (a) obesitas sentral (lingkar pinggang $>102 \mathrm{~cm}$ untuk pria dan $>88 \mathrm{~cm}$ untuk wanita); (b) hypertriglyceridemia (kadar trigliserida $\geq 150$ $\mathrm{mg} / \mathrm{dL}$ atau dalam medikasi spesifik); (c) Kadar HDL kolesterol rendah $(<40 \mathrm{mg} / \mathrm{dL}$ untuk pria and $<50 \mathrm{mg} / \mathrm{dL}$ untuk wanita, atau dalam medikasi spesifik); (d) hipertensi (tekanan darah sistolik $\geq 130 \mathrm{mmHg}$ atau tekanan darah diastolik $\geq 85 \mathrm{mmHg}$ atau dalam medikasi spesifik); (e) kadar gula darah puasa $\geq 100 \mathrm{mg} / \mathrm{dL}$ atau dalam medikasi spesifik atau sebelumnya terdiagnosis diabetes mellitus tipe 2 (Eckel, 2015).. 
Lingkar pinggang berkorelasi kuat dengan obesitas dan risiko kardiovaskular. Lingkar pinggang terbukti lebih efektif dalam mendiagnosis sindroma metabolik dibandingkan dengan indeks massa tubuh (IMT) dan ukuran antropometri lainnya. Hal ini membuktikan pengukuran lingkar pinggang merupakan cara yang mudah, murah, dan efektif dalam mendeteksi sindroma metabolik. Orang dengan obesitas berisiko mengalami peningkatan kadar gula darah. Sebuah penelitian dilakukan oleh Karimah 2018 Rasio lingkar pinggang-panggul memiliki hubungan yang kuat dengan kadar glukosa darah dibandingkan dengan indeks massa tubuh

\section{METODE PELAKSANAAN}

Pengabdian masyarakat ini akan dilaksanakan dengan metode promotif berupa penyuluhan dan pemeriksaan yang disampaikan dalam bentuk visualisasi. Sasaran kegiatan ini adalah ibu-ibu pengajian Desa Pisangan Jaya, Kecamatan Sepatan, Kabupaten Tangerang dengan metode pengabdian yaitu : Memberikan penjelasan mengenai berat badan ideal, dengan cara memberikan pemahaman, Melakukan pemeriksaan glukosa darah metode POCT, dan melakukan pemeriksaan ligkar perut. Evaluasi dilakukan dengan menilai antusias ibu-ibu untuk melaksanakan pemeriksaan kadar glukosa darah sewaktu dan lingkar perut.

\section{HASIL DAN PEMBAHASAN}

Kegiatan pengabdian dilakukan pada hari Jum'at tanggal 26 oktober 2018 di Musholla Desa Pisangan Jaya, Kecamatan Sepatan, Tangerang. Kegiatan pengabdian dilakukan berupa penyuluhan kesehatan dan pemeriksaan glukosa darah sewaktu menggunakan alat easy touch secara gratis. Peserta pengabdian masyarakat adalah ibuibu pengajian dengan total peserta yang mengikuit pemeriksaan glukosa darah sewaktu sebanyak 20 orang. Rentang umur peserta dari umur 24 tahun hingga 70 tahun.

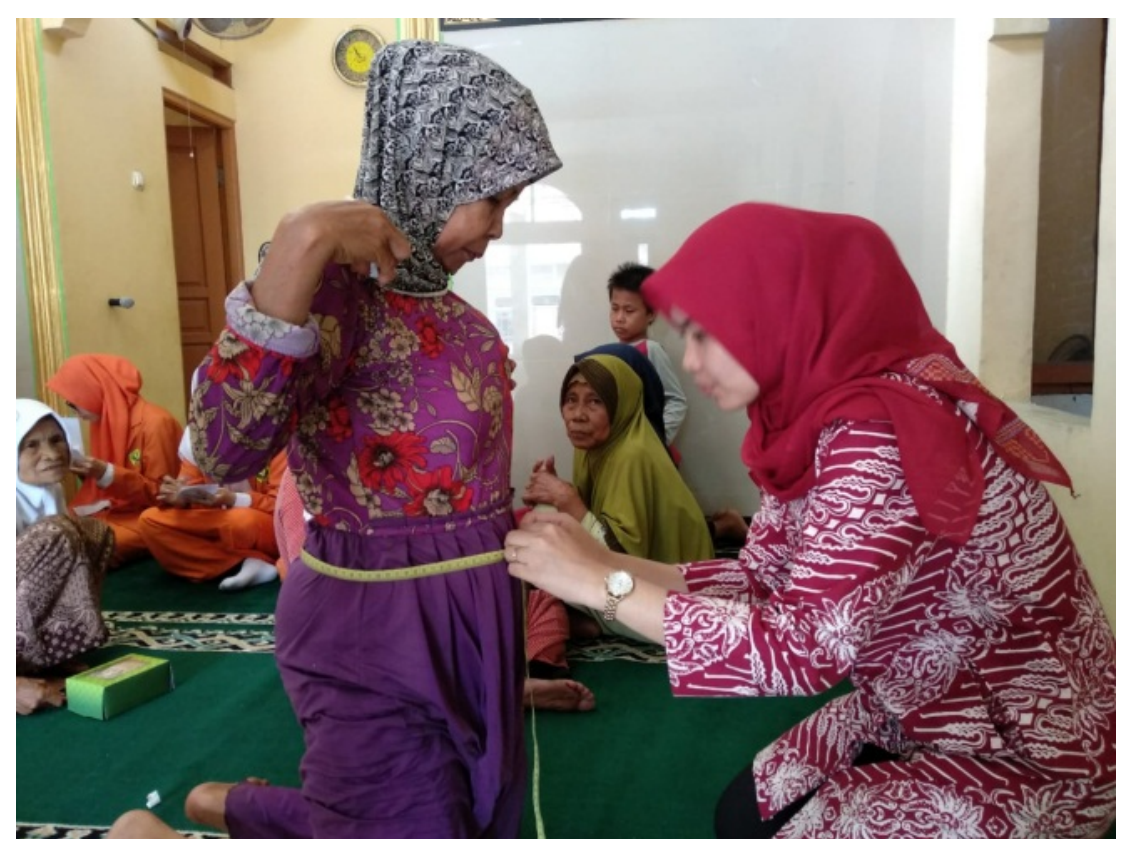

Gambar 1. Pengukuran Lingkar Perut 


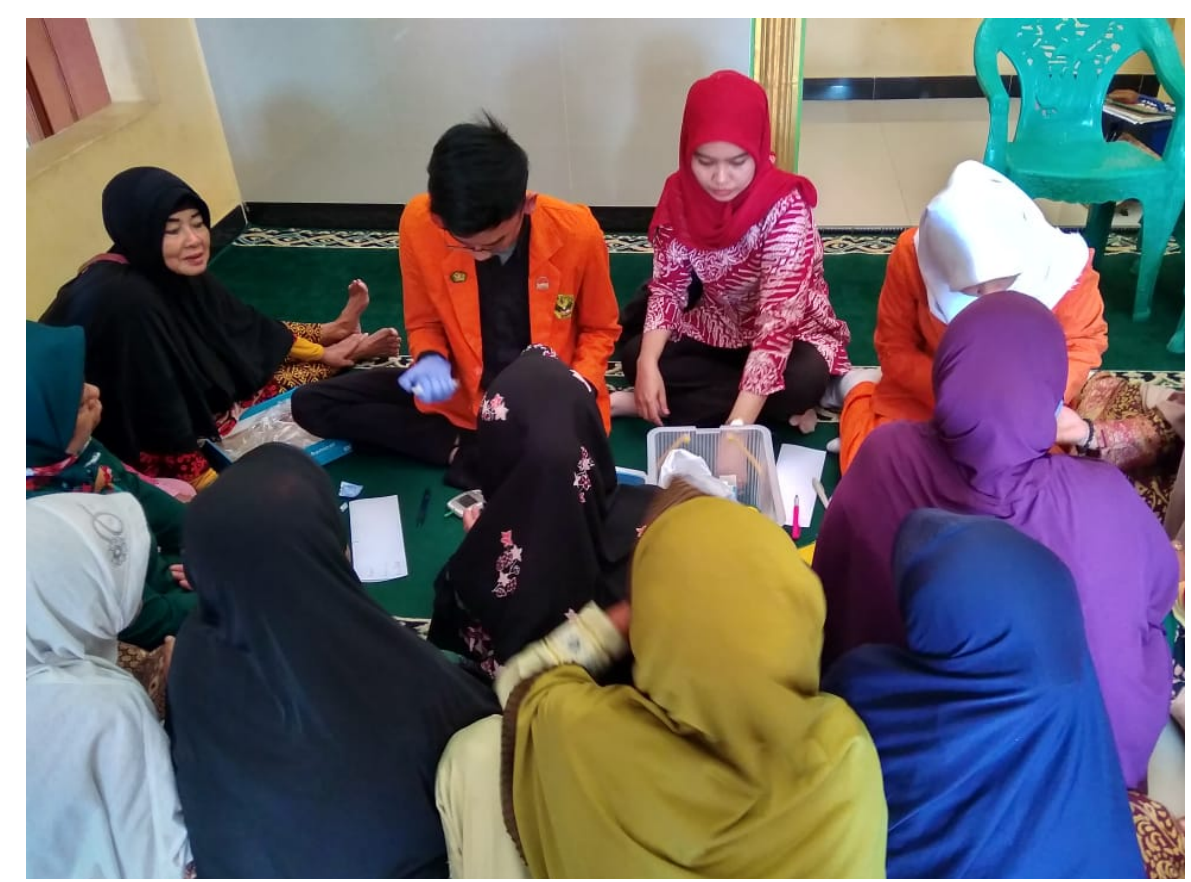

Gambar 2. Pemeriksaan Glukosa darah sewaktu

Dari hasil pemeriksaan lingkar perut diketahui rata-rata lingkar perut ibu-ibu pengajian di Desa Pisangan Jaya yang mengikuti pemeriksaan sebesar $89 \mathrm{~cm}$. Rata-rata umur peserta yang mengikuti pengabdian masyarakat ialah 47 tahun, yang tertua berumur 70 tahun dan termuda 24 tahun. Rata-rata kadar glukosa darah sewaktu ialah $106 \mathrm{mg} / \mathrm{dl}$ dengan kadar tertinggi $235 \mathrm{mg} / \mathrm{dl}$ dan terendah $67 \mathrm{mg} / \mathrm{dl}$.

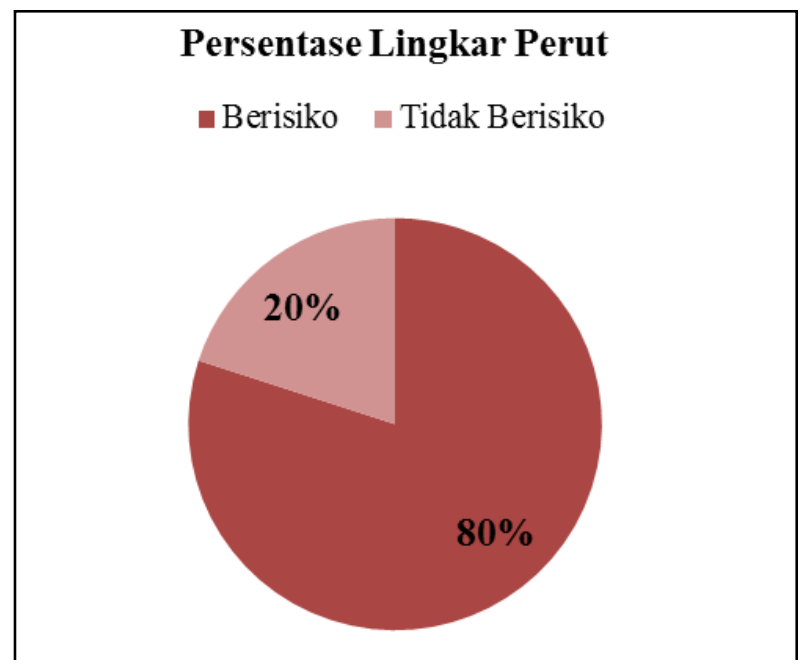

Gambar 3. Persentase Hasil Pemeriksaan Lingkar Perut

Total yang melakukan pemeriksaan adalah 20 orang. Hasil pengukuran lingkar perut 16 orang atau $80 \%$ dari total peserta memiliki lingkar perut $\geq 88 \mathrm{~cm}$. Lingkar perut merupakan salah satu faktor resiko untuk penyakit diabetes militus tipe II. Kurangnya aktifitas fisik, hipertensi, dan dislipidemia juga akan meningkat resiko penyakit diabates (Noor, 2015). Menurut Triwinarto, 2012 lingkar perut lebih baik sebagai indikator risiko diabetes pada orang dewasa di indonesia.

Hasil pemeriksaan glukosa darah sewaktu ditemukan satu orang dengan kadar 
glukosa darah melebihi batas normal ( $\leq 200 \mathrm{mg} / \mathrm{dl}$ ) yaitu $235 \mathrm{mg} / \mathrm{dl}$. Peserta dengan kadar glukosa melebih normal ini juga memiliki lingkar perut melebihi dari batas normal. Kadar glukosa darah lebih dari normal atau hiperglikemia merupakan indikator bahwa adanya sindrome metabolik yang diderita oleh pasien. Peserta dengan kadar glukosa tinggi ini telah diberikan pemahaman untuk lebih menjaga kesehatan, memperbaiki pola makan, dan disarankan untuk melakukan senam sehat setiap hari.

Secara keseluruhan kegiatan pengabdian masayrakat ini berjalan lancar indikator adanya keinginan unutk menjaga kesehatan adalah antusias ibu-ibu untuk mengikuti pemeriksaan glukosa darah dan lingkar perut. Setelah pemeriksaan ibu-ibu juga banyak memberikan pertanyaan mengenai cara menjaga kesehatan. Setelah melakukan pemeriksaan ibu-ibu pengajian juga diajak untuk melakukan senam GERMAS harapannya ibu-ibu di Desa Pisangan Jaya, kecamatan Sepatan lebih menyadari pentingnya mejaga kesehatan dan dapat merapkan pola hidup yang sehat.

\section{KESIMPULAN}

Kegiatan pengabdian masyarakat di Desa Pisangan Jaya Kecamatan Sepatan berjalan lancar dan peserta melakukan pemeriksaan glukosa darah dan lingkar perut. Setelah dilakukan pemeriksaan ibu-ibu peserta pengabdian masyarakat nampak lebih ingin lebih menjaga kesehatan dilihat dari antusias mereka dalam melakukan pemeriksaan dan berdiskusi tentang hasil pemeriksaan tersebut.

\section{DAFTAR PUSTAKA}

[1]. American Diabetes Association. 2006. Supplement 1 American Diabetes Association: Clinical Practise Recommendations. Diab Care. 2006;29

[2]. Eckel R. 2015. Metabolic Syndrome. In: Kasper D, Hauser S, Jameson J, Fauci A, Longo D, Loscalso J, editors. Harrison's Principles of Internal Medicine. 19th ed. McGraw-Hill Education;.p.2449-50.

[3]. International Diabetes Federation. 2015. Atlas de La Diabetes de La FDI. International Diabetes Federation. https://doi.org/10.1289/image.ehp.v119.i03.

[4]. Jalal F, Liputo N, Susanti N, Oenzil F. 2006.Hubungan lingkar pinggang dengan kadar gula darah, trigliserida dan tekanan darah pada etnis Minang di kabupaten Padang Pariaman, Sumatera Barat.

[5]. Karimah, M. 2018. Rasio Lingkar Pinggang-Panggul Memiliki Hubungan Paling Kuat Dengan Kadar Glukosa Darah. Jurnal Berkala Epidemiologi. Volume 6, Nomor 3.

[6]. Badan Penelitian dan Pengembangan Kesehatan. 2013. "Riset Kesehatan Dasar (RISKESDAS) 2013.” Laporan Nasional 2013, 1-384. https://doi.org/1 Desember 2013

[7]. Noor, F. R. 2015. Dibates Militus Tipe 2. Artikel Review. J. Majority. Volume 5 Nomor 5.

[8]. Triwinarto, A., Muljati, S., Jahan, A.B., 2012. Cut Off Point Indeks Massa Tubuh (Imt) Dan Lingkar Perut Sebagai Indikator Risikodiabetes Dan Hipertensi Pada Orang Dewasa Di Indonesia. Penel Gizi Makan. 35(2): 119-135. 10.1017/CBO9781107415324.004

[9]. World Health Organization. 2016. “Global Report on Diabetes.” Isbn 978:88. https://doi.org/ISBN 9789241565257. 